\title{
LEGACY OF THE STATE: PRIOR SHARED EXPERIENCE AND SURVIVAL OF SPIN-OFFS FROM RESTRUCTURED STATE ENTERPRISES
}

\author{
Ilya Okhmatovskiy \\ Universidade Nova de Lisboa \\ Olga Suhomlinova \\ University of Leicester \\ Laszlo Tihanyi \\ Texas A\&M University
}

October 2018

Forthcoming in Journal of Management

Corresponding author: Ilya Okhmatovskiy (ilya.okhmatovskiy@novasbe.pt) NOVA School of Business and Economics, Universidade Nova de Lisboa, Capmus de Carcavelos, Rua da Holanda 1, Carcavelos, 2775-405 Portugal. 


\begin{abstract}
Many organizations, especially in emerging economies, trace their origins to restructured state enterprises and this study explores the implications of such origins for organizational adaptation to changing environmental conditions. We compare the activity choices and survival chances of spin-offs from restructured state enterprises with those of de novo organizations. We argue that prior shared experience of spin-offs' managers and employees facilitates the redeployment of routines developed in parent state enterprises. This should predispose spin-offs to pursue familiar activities, but this choice is not completely predetermined and its survival implications depend on the environmental conditions. Our empirical findings suggest that spin-offs from restructured state enterprises are less likely to engage in the new activities than de novo organizations. However, those restructuring spin-offs that do engage in the new activities before the regulatory regime shift significantly improve their survival chances after the shift. Moreover, we find that the detrimental effect of the regulatory regime shift and the beneficial effect of engaging in new activities are stronger for spin-offs from restructured state enterprises than for de novo organizations.
\end{abstract}

Keywords: State enterprises, Regulatory regime shift, Organizational origins, Prior shared experience, Organizational activities, Restructuring spin-offs 


\section{LEGACY OF THE STATE: PRIOR SHARED EXPERIENCE AND SURVIVAL OF SPIN-OFFS FROM RESTRUCTURED STATE ENTERPRISES}

The effect of organizational origins on survival has been the focus of a growing number

of studies in recent years (Bayus \& Agarwal, 2007; Chen et al., 2012; Geroski et al., 2010). Previous work has demonstrated that the ways organizations are created may be associated with advantages and disadvantages that can last over the organizations' entire life-cycle. A number of studies investigated these advantages and disadvantages by comparing new ventures created from scratch with ventures established as spin-offs from existing organizations (e.g., Klepper \& Sleeper, 2005; Phillips, 2002; Shane \& Stuart, 2002).

Ventures established as spin-offs often originate from organizations that were previously owned by the state (Oertel, Thommes, \& Walgenbach, 2016; Suhomlinova, 1999; Woolley, 2017). Over the last several decades, privatization waves in the United Kingdom, France, Brazil, China, Russia, and countries of Central and Eastern Europe created thousands of new ventures by restructuring local state-owned enterprises (Megginson \& Netter, 2001). State-owned enterprises were usually inefficient, too large, and possessed limited innovative capabilities (Filatotchev, Buck, \& Zhukov, 2000). To address these organizational and the resulting macroeconomic problems, governments often decided to restructure the large state-owned enterprises by splitting them into multiple legal entities that were subsequently privatized (Suhomlinova, 1999; Xu, Tihanyi, \& Hitt, 2017). ${ }^{1}$

The implications of creating new organizations from restructured state enterprises have received rather limited attention to date (Sedaitis, 1998; Woolley, 2017). To better understand the strategic choices made by spin-offs from restructured state enterprises, we rely on recent literature that highlights the importance of prior shared work experience (Autio, George, \& 
Alexy, 2011; Fern, Cardinal, \& O’Neill, 2012; Zheng, Devaughn, \& Zellmer-Bruhn, 2016). Viewed from this perspective, spin-offs from restructured state enterprises are expected to make strategic choices that reflect the prior shared experience of their organizational members. To investigate the implications of prior shared work experience in state enterprises, we pose the following research question: How does prior shared experience affect activities of spin-offs originating from restructured state enterprises and the ability of these spin-offs to adapt to changing environmental conditions? To answer this question, we examine systematic differences between spin-offs from restructured state enterprises and newly-established (de novo) organizations in their activity choices and survival rates before and after a major change in the regulatory environment.

We refer to the new organizations created as a result of restructuring of state enterprises as "restructuring spin-offs" (Parhankangas \& Arenius, 2003). Unlike entrepreneurial ventures created to exploit new technologies, new market niches, or new business models (Narayanan et al., 2009), these restructuring spin-offs are created in the privatization process driven by the government goals. We argue that restructuring spin-offs inherit organizational routines developed through prior shared experience of their managers and employees. This prior shared experience predisposes organizations to engage in familiar activities that can be performed by relying on the inherited routines. We build on the transactive memory systems (TMS) theory (Brandon \& Hollingshead, 2004; Lewis, Lange, \& Gillis, 2005; Peltokorpi, 2008; Ren \& Argote, 2011; Wegner, 1987) to explain how prior shared experience affects the activity choices of restructuring spin-offs and to investigate the survival implications of such activity choices. Market reforms in transition economies tend to be associated with a large-scale restructuring of state enterprises and, at the same time, with massive founding of de novo 
organizations (Estrin, Meyer, \& Bytchkova, 2005; Lyles, Saxton, \& Watson, 2004; Wachtel, 1999). The emergence of a large number of diverse organizations over a relatively short period of time provides an opportunity to compare organizations with and without pre-founding experience. Our empirical analysis is focused on commercial banks during the market reforms in Russia when the restructuring spin-offs from the Soviet-era banks leveraged their pre-founding experience to compete against de novo banks created from scratch. Our observation period from 1988 to 2002 enables us to analyze the banking industry before and after major changes in the regulatory environment that occurred in 1995 when the Russian government moved from laissezfaire policies to tight regulation and hard budget constraints.

Our study makes a contribution to the literature by demonstrating that the "legacy of the state" is particularly strong in those organizations where managers and employees share collective experience of working for state enterprises. We also advance the literature on organizational origins by showing how prior shared experience can boost or hamper survival chances depending on environmental conditions. Furthermore, our results suggest that the risks associated with prior shared experience are more pronounced when organizational founding is not motivated by the intent to engage in new activities.

\section{THEORETICAL BACKGROUND}

Previous studies suggest that the prior experience of founders strongly influences their choices in running new ventures and the success of these ventures. The importance of prior experience was often attributed to knowledge and capabilities acquired as a result of such experience (Agarwal et al., 2004; Campbell et al., 2012; Dencker et al., 2009; Helfat \& Lieberman, 2002; Klepper \& Sleeper, 2005). One stream within this literature emphasized the critical role played by collective or shared experience in the development of knowledge and 
capabilities (Agarwal et al., 2016; Eisenhardt \& Schoonhoven, 1990; Ganco, 2013). Researchers pointed out that prior individual experiences may not be sufficient for the transfer of capabilities to new organizations because these capabilities are grounded in routines performed by teams and prior shared experience of team members is critical for successful reproduction of these routines in another organization (Fern et al., 2012; Reagans, Argote, \& Brooks, 2005; Wezel et al., 2006).

Whereas previous studies explained the importance of prior shared experience from the knowledge-based perspective (e.g., Agarwal et al., 2016; Ganco, 2013), useful insights can also be drawn from psychological theories about collective cognitive processes. To explain how collective or shared knowledge is accumulated, stored, transferred, and deployed by people working together, psychologists studying cognitive processes in social groups use concepts of team mental models (Edwards et al., 2006; Klimoski \& Mohammed, 1994; Mathieu et al., 2000; Mohammed et al., 2010) and TMS (Liang, Moreland, \& Argote, 1995; Peltokorpi, 2008; Wegner, 1987). These concepts emphasize the importance of interpersonal interactions in the processes of developing and deploying collective cognitive structures. The concept of TMS, in particular, has been embraced by management scholars to emphasize the interactive nature of knowledge accumulation and maintenance in organizations (Ren \& Argote, 2011). For example, Hecker (2012) suggests TMS as a theoretical framework that captures distinctive characteristics of knowledge shared among organizational members. Miller et al (2014) and Argote and Guo (2016) conclude that the development of organizational routines is associated with TMS.

The idea that interactive cognitive processes represent a critical aspect of prior shared experience goes back to the management classics. According to Penrose, "An administrative group is something more than a collection of individuals; it is a collection of individuals who have had experience in working together... Extensive planning requires the cooperation of many 
individuals and this requires knowledge of each other" (1959: 46-47). Similarly, Nelson and Winter argued: "To view organizational memory as reducible to individual member memories is to overlook, or undervalue, the linking of those individual memories by shared experiences in the past, experiences that have established the extremely detailed and specific communication system that underlies routine performance." (1982: 105).

More recently, collective cognition as a critical aspect of prior shared experience has been emphasized by Berman et al. (2002), Kor (2003), Beckman (2006) and Zheng et al (2016). Among the studies that attribute the effects of prior shared experience to collective cognitive processes, some describe these processes using the concept of TMS (e.g., Ren \& Argote, 2011; Zheng, 2012) and others employ the concepts of shared mental models, collective mind, or distributed tacit knowledge (e.g., Beckman, 2006; Berman et al., 2002). Despite terminological differences, these studies rely on the same explanatory logic emphasizing collective cognitive processes as a critical aspect of prior shared experience. We use the concept of TMS because it has emerged as a dominant concept in the research on shared knowledge (Argote \& Guo, 2016; Hecker, 2012) and because it effectively captures the cognitive and interactive aspects of prior shared experience.

TMS are defined as "the shared division of cognitive labor with respect to the encoding, storage, retrieval, and communication of information from different knowledge domains, which often develops in close relationships" (Brandon \& Hollingshead, 2004: 633). TMS are created as a result of interactions among group members as they learn "who knows what" (Peltokorpi, 2008; Ren \& Argote, 2011; Wegner, 1987). Effective performance of organizational routines requires the development of TMS because the execution of most routines requires joint participation by multiple employees who rely on their shared knowledge and experience. 
Researchers have emphasized the importance of cognitive and interactive aspects of routines (Becker, 2004) and recent publications demonstrate how the concept of TMS helps us better understand these cognitive and interactive aspects of organizational routines (Argote \& Guo, 2016; Miller et al., 2014). When an organizational unit becomes a stand-alone organization, employees who worked together in the parent organization tend to preserve TMS that facilitate the effective execution of routines in spin-off organizations. This creates a tendency to engage in activities that can be performed by relying on familiar routines.

Activities are complex combinations of routines. Some routines may be unique for a given activity while other routines are used in several activities. For example, extending loans to private enterprises is an activity based on routines, such as reading a balance sheet or calculating appropriate interest rates to be charged. Some organizations may engage mostly in activities that leverage familiar routines while other organizations may engage in new activities and thus have to develop new routines. Even though organizational origins may predispose organizations to engage in particular activities, the choice of activities is not completely predetermined, and it is particularly interesting to study the survival implications of deviating from the choice of activities associated with certain organizational origins. In this paper, we explain how organizational origins and prior shared experience affect the choice of activities and consider the implications of this choice for organizational survival.

Since organizational survival depends on a fit between the organization and the environment, it is important to examine how the survival consequences of particular organizational origins may be affected by a significant environmental change (Chen et al., 2012; Ganco and Agarwal, 2009). We anticipate that the survival implications of the activity choices would be contingent upon environmental conditions and would ultimately depend on the extent 
to which specific activities promote the fit between the organization and its environment. We are particularly interested in the effect of a permanent shift ${ }^{2}$ in the environmental conditions that is produced by substantial changes in the regulatory regime (Haveman et al., 2001).

Restructuring of state enterprises is often triggered by market reforms that also bring major changes in the institutional environment. Some studies consider market reforms as an undifferentiated period of institutional turbulence (e.g., Newman, 2000). However, a finergrained analysis would show the distinct stages of the reform process. Usually market reforms start with dismantling of the existing institutions, a process during which the elaborate mechanism of centralized coordination of transactions among economic actors is disabled and these economic actors are set free to choose transaction partners as well as contractual conditions. Early studies of market reforms usually focused on the process of market liberalization and on the consequences of dismantling the system of centralized coordination of economic activities (e.g., Boycko, Shleifer, \& Vishny, 1994; Filatotchev, Buck, \& Wright, 1992). The next stage of market reforms becomes the development of institutions that regulate interactions among market participants (Kogut \& Spicer, 2002). Both processes - dismantling of old rules and development of new rules - can be implemented gradually or abruptly (Spicer, McDermott, \& Kogut, 2000). In this study, we focus on abrupt changes in the regulatory environment associated with the introduction of new regulations after the initial period of market liberalization. We argue that the survival implications of organizational origins will be moderated by the regulatory regime shift, because major regulatory changes create more challenges for organizations of particular origins.

\section{HYPOTHESIS DEVELOPMENT}

Employees of spin-offs often have shared experience of working together for the parent 
organization. In the case of spin-offs operating in the parent organization's industry, we can speak of industry-specific prior shared experience (Fern et al., 2012; Zheng et al., 2016). This concept emphasizes two conditions: (1) a group of employees used to work together (shared experience), and (2) this group used to work together in the same industry, in which it works currently (industry-specific experience). In contrast, employees of de novo organizations may have individual industry-specific experiences but they usually lack the shared experience or they may have such shared experience acquired in another industry.

The theory of TMS clarifies why shared experience is qualitatively different from individual experience. Shared experience enables the development of collective cognitive models that facilitate interpersonal coordination required for the effective execution of organizational routines. If individuals with shared experience continue working together, their TMS is preserved. If these individuals join different organizations, their individual experiences would not match the experiences of new co-workers and a new TMS would have to be developed.

Since restructuring spin-offs possess industry-specific prior shared experience, they can redeploy TMS developed in their parent organizations. Through TMS that "facilitate access to a library of pre-existing behavioral routines or knowledge" (Zheng \& Mai, 2013: 201-202), prior shared experience enhances organizational ability to execute familiar routines. Proficiency in executing familiar routines predisposes spin-offs to engage in the activities that are similar to those performed by their parent state enterprises. We contrast these traditional activities that were performed by incumbent organizations in the past with new activities. Activities are new if most organizations in a given industry have very limited experience of performing them. ${ }^{3}$

Restructuring spin-offs' propensity to engage in traditional activities is buttressed by the tendency of organizational founders to “select a strategy element that reflects the team's shared 
experience and represents a tie to the team's collective past” (Fern et al., 2012: 433). This propensity also reflects the fact that, as domain insiders, spin-off managers often "struggle to recognise and execute competence-destroying changes" (Furr, Cavarretta \& Garg, 2012: 252). In contrast, de novo organizations lack industry-specific prior shared experience and will be less inclined to engage in traditional activities. Unlike spin-offs, de novo do not inherit TMS that can be leveraged by performing familiar activities. This would make de novo organizations more open to engaging in new activities. Furthermore, executives of de novo organizations often have experience outside the focal industry, and such experience facilitates exploration and experimentation. As “domain outsiders", such executives can bring new ideas and identify promising opportunities and novel solutions (Furr et al., 2012). Previous studies reported that de novo organizations are more likely to engage in product innovation (Khessina, 2003) and learn by experimenting (Bradley et al., 2011). Based on these arguments, we suggest:

\section{Hypothesis 1. Spin-offs from restructured state enterprises are less likely to engage in} new activities than de novo organizations.

As we argued above, the survival implications of engaging in new activities will be contingent on environmental conditions. Restructuring spin-offs may benefit from pursuing activities similar to those performed by their parent organizations as long as the environmental conditions make those activities feasible and profitable. The relevance of prior shared experience is determined by conditions of the task environment. If the task environment does not change substantially, prior shared experience remains relevant and TMS developed through this experience remain instrumental (Zheng, 2012). At the same time, in the absence of substantial changes in the business environment, the tendency of de novo organizations to experiment with new activities will be associated with a higher risk of failure. 
In line with the prior literature about the survival advantages associated with relevant prefounding experience (Agarwal et al., 2004; Dencker \& Gruber, 2015; Helfat \& Lieberman, 2002; Klepper, 2009), we expect restructuring spin-offs to have lower mortality hazards than de novo organizations as long as activities similar to those performed by their parent organizations earlier remain relevant and profitable. This condition stems from our argument that prior shared experience and TMS predispose organizations to engage in familiar activities. Performing familiar activities is associated with lower risk and higher efficiency. Therefore, we expect restructuring spin-offs to have the survival advantages over de novo organizations before a regulatory regime shift:

Hypothesis 2. Spin-offs from restructured state enterprises will have higher survival chances than de novo organizations before the regulatory regime shift.

Enjoying success today may increase the risk of failure tomorrow if environmental conditions change. Previous success of an organization's strategy makes it difficult to change strategic direction, the phenomenon called "co-evolutionary lock-in" (Burgelman, 2002). Perfect adaptation to a specific competitive landscape may be a drawback, because the organizations that have achieved a perfect fit with a particular environment tend to be at a disadvantage when the environment changes, as described in studies about "competency trap" (Barnett et al., 1994; Levitt \& March, 1988). TMS developed through prior shared experience remain useful in similar task environments but become less relevant once task environments change (Brandon \& Hollingshead, 2004; Zheng, 2012). In introducing Hypothesis 2, we argued that before the regulatory regime shift restructuring spin-offs can take advantage of relevant prior shared experience of their managers and employees. However, the task environment and, therefore, the relevance of collective cognitive models developed based on prior shared experience (Beckman, 
2006; Berman et al., 2002; Kor, 2003) will change after the regulatory regime shift. Building on our arguments that the restructuring spin-offs are more likely to engage in familiar activities, and that the benefits of such activities decrease after a regulatory regime shift, we suggest that:

Hypothesis 3. The regulatory regime shift will have a negative effect on the survival of spin-offs from restructured state enterprises.

The effect of a regulatory regime shift on de novo organizations is more difficult to predict. We expect that the organizations without inherited routines are more likely to engage in new activities which, in turn, should facilitate adaptation to the changed environmental conditions (Benner \& Tushman, 2003; Zollo \& Winter, 2002). Yet, even the organizations open to engaging in new activities may experience difficulties in adapting to a new environmental landscape after the shift (Bradley et al., 2011). Environmental changes create challenges as well as opportunities, and the nature of these changes will determine whether the detrimental effect of challenges on organizational survival will exceed the positive effect of opportunities. We argued earlier that TMS developed through prior shared experience become less relevant after the shift. However, de novo organizations lack industry-specific prior shared experience and thus would not suffer from decreased relevance of such experience after the regulatory regime shift.

While we hypothesize that the regulatory regime shift will increase the hazard of mortality for spin-offs, we cannot unambiguously predict the effect of the regulatory regime shift on the survival of de novo organizations. Our argument, however, yields an unequivocal prediction when we compare how the de novo and the restructuring spin-offs are affected by the regulatory regime shift. We predict that de novo organizations will adapt better to the new environmental conditions than restructuring spin-offs that, in their majority, have been engaging in traditional activities before the regulatory regime shift. This suggests the following 
hypothesis:

Hypothesis 4. The regulatory regime shift will have a stronger negative effect on the survival of spin-offs from restructured state enterprises than on the survival of de novo organizations.

Although their pre-founding experience predisposes restructuring spin-offs to engage in familiar activities, some of them may develop new routines as a result of experimenting with novel activities. Researchers argued that engaging in new activities forces organizations to develop new TMS (Bryant, 2014; Ren, Carley, \& Argote, 2006). Performing new complex tasks requires organizational members to identify who has relevant knowledge and to learn how to integrate such knowledge. As a result, organizations acquire valuable experience of new TMS development that may boost their adaptive capacity (Argote \& Ren, 2012). Correspondingly, we expect that the experience of engaging in new activities before the regulatory shift will help restructuring spin-offs to adapt to the environment after the regulatory change. Therefore, the argument about the disadvantages of restructuring spin-offs in the post-shift environment that underpins Hypothesis 3 will not apply to those restructuring spin-offs that engage in new activities before the regulatory regime shift. In other words, engaging in new activities is expected to reduce the risks associated with the inheritance originating in the prior experience of operating as a unit of a state enterprise.

Hypothesis 5: Engaging in new activities before the regulatory regime shift will have a positive effect on the survival of spin-offs from restructured state enterprises after the regulatory regime shift.

Whereas engaging in new activities before the regulatory regime shift might be beneficial for both restructuring spin-offs and de novo organizations, such experience is particularly critical 
for boosting the survival chances of spin-offs originating from restructured state enterprises. Prior shared experience and established TMS create obstacles that make engaging in new activities more difficult for restructuring spin-offs than for de novo organizations. However, we expect that spin-offs will also benefit more from engaging in new activities compared to the de novo, for two reasons. First, the tendency of restructuring spin-offs to take advantage of the inherited routines and established TMS makes them particularly vulnerable to changes in the regulatory regime. This vulnerability can be alleviated as the result of experimenting with new activities. Among restructuring spin-offs, engaging in new activities is an important signal that they have been able to overcome the rigidity associated with routines developed through prior shared experience. However, among the de novo, engaging in new activities is not an indicator that distinguishes adaptive organizations from rigid organizations.

Second, experimenting with new activities provides an opportunity for restructuring spinoffs to modify existing TMS and to change their established routines, while de novo organizations experimenting with new activities do not change their established routines, they build them from scratch. The experience of changing established routines would be particularly relevant after the regulatory regime shift because this shift will force all organizations to transform the ways they operate. For these reasons, we expect that the survival advantages of engaging in new activities will be conditional on organizational origins. Specifically, we suggest: Hypothesis 6: Engaging in new activities before the regulatory regime shift will have a stronger positive effect on the survival after the shift for spin-offs from restructured state enterprises than for de novo organizations.

Figures $1 \mathrm{a}$ and $1 \mathrm{~b}$ depict our conceptual model and the hypothesized relationships. 


\section{RESEARCH CONTEXT}

We tested our hypotheses using data on the Russian commercial banking industry over the 15 years following its inception in 1988 . This empirical context is particularly advantageous for testing our hypotheses for three reasons. First, a large number of banks were founded and liquidated in Russia between 1988 and 2002, and the available records allowed us to trace the origins, the founding date, and the liquidation date (if applicable) for all these banks. Second, there is a stark contrast in the origins and the pre-founding experience between the de novo banks and the restructuring spin-offs created on the basis of the branches of the former Soviet banks. Third, the Russian banking industry experienced a major shift in the regulatory regime in 1995.

\section{The Emergence of the Russian Commercial Banking Industry}

Before the emergence of commercial banking in 1988, banks in the Soviet Union operated under exclusive state control and served as an instrument for the centralized distribution of state funds. The system bore little resemblance to commercial banking. It was comprised of several giant banks, each specializing in a particular economic sector. The birth of the Russian commercial banking industry was marked by two events. The first was the adoption of the Law on Cooperatives in 1988, which permitted to set up commercial banks. This led to the emergence of de novo banks, which were start-ups created by individuals, enterprises, governmental agencies, or non-commercial organizations. These de novo banks could draw on the financial, social, and human capital of their founders, but they were created without involvement of the Soviet-era banks. The second event was the 1990 ruling by the Central Bank of Russia to transform the branches of the Soviet state banks into independent commercial banks by allowing the branch managers and employees to form new banks from their branches (Abarbanell \& 
Meyendorff, 1997). This event led to the creation of hundreds of restructuring spin-off banks that inherited the assets, liabilities, managers and employees of the former Soviet bank branches (see Appendix for information about prior employment of top managers at a sample spin-off bank).

\section{The Regulatory Regime Shift}

The first 15 years of the Russian commercial banking industry were characterized by high environmental uncertainty and volatility stemming from general macroeconomic instability. Prior to 1995, the reformist government mainly focused on privatization and market liberalization, paying only scant attention to the regulation of the banking industry. From 1988 to 1991, the commercial banking was virtually unregulated, which resulted in the unbridled growth in the number of banks from 6 to 1,360. In 1991, the Central Bank of Russia formally assumed a role of the industry regulator, but its initial licensing policies were relatively liberal, the prudential regulations were lax, and the enforcement was poor. Consequently, the banking boom continued unchecked, with the number of banks expanding to 2,517 by the end of 1994 .

In 1995, the Russian government was forced to abandon its laissez-faire policies with regard to commercial banking and to resort to stricter regulations in order to gain control over the rampant inflation and chaotic financial markets (Barisitz, 2004). In July 1995, it introduced the currency corridor limiting the exchange rate fluctuations. The government's commitment to noninflationary funding of the budget deficit decreased the inflation rate from 130 percent in 1995 to 22 percent in 1996. The new government policies as well as the tightened regulations and licensing requirements of the Central Bank dramatically changed the business environment of the Russian banking industry. The number of banks had fallen to 2,029 by 1996 and to 1,600 by 1998. The regulatory regime shift of 1995 was a "point of no return" that radically altered the conditions of operating in the banking industry. ${ }^{4}$ 
Before the regulatory regime shift, spin-off banks often made money through redistributing centrally-allocated funds to state enterprises served earlier by their parent Soviet banks. As long as this business model remained profitable, spin-off banks had limited motivation to engage in new activities to exploit opportunities created by market liberalization. In contrast, de novo banks lacked an established client base and had limited opportunities to distribute lowinterest loans funded by the Central Bank. They had to explore other opportunities and this prompted de novo banks to engage in new activities, such as arbitrage and intermediation in financial markets, international money transfers, and searching for new clients in the growing population of private enterprises.

Anti-inflationary policies and tightened regulatory requirements introduced in 1995 effectively eliminated the opportunities for making easy profits that banks used to exploit in the early 1990s. The Central Bank no longer provided loans on favorable conditions and the spinoffs' heavy reliance on the inherited client base created a problem of connected lending that compromised the loan portfolios of many spin-off banks with non-performing loans. Although the regulatory regime shift destroyed some sources of income that many de novo banks exploited before the shift, such as market arbitrage in the high-inflation economy, the development of financial markets and the growing demand for financial services created new opportunities for the banks. At the same time, the tightened monetary policy and stricter regulations posed threats to the survival of both the de novo and the spin-offs. These changing environmental conditions provide us with an opportunity to test our hypotheses about factors affecting the survival of de novo and spin-off banks. 


\section{METHODS}

\section{Data}

Our data on organizational origins, founding date, size, location, and date and type of exit cover the entire population of commercial banks in Russia from its inception in 1988 until 2002. During this period, 3068 banks were founded, but by September 2002 only 1333 banks remained in operation. Our data on the registered capital cover 1178 banks founded by May 1991, and the data on the foreign correspondent accounts and the structure of loan portfolios at the end of 1994 are available for 332 banks. The main sources of data for this study were the official registry of banks maintained by the Central Bank of Russia and the directories of Russian commercial banks compiled by the information agencies "Inform-servis", "Intelbridge", and "Konsultbankir."

\section{Dependent Variable}

In the analysis of survival ${ }^{5}$, our dependent variable is the hazard rate of liquidation. The hazard rate $h$ for firm $i$ and time $t$ can be expressed as

$$
h_{i t}=\lim _{d t \rightarrow 0} \frac{\operatorname{Pr}(t \leq T<t+d t \mid T \geq t)}{d t}
$$

where $T$ is waiting time until the event occurrence and $\operatorname{Pr}(t \leq T<t+d t \mid T \geq t)$ is the conditional probability that the event will occur between $t$ and $t+d t$ given that it has not occurred before $t$.

In principle, there are two types of exit from an organizational population: through liquidation and through acquisition. Following Mitchell (1994) and Fortune and Mitchell (2012), we recognize that the characteristics that make organizations likely to fail may significantly differ from those that make them likely to be acquired. In our analysis, we focus on exits through liquidation because they represent "true failures," while both successful and unsuccessful banks may become targets of acquisition (Wheelock \& Wilson, 2000). Out of the total 1727 exits from the industry during the observation period, 1370 were liquidations and 357 were acquisitions. 


\section{Independent Variables}

Organizational origins. Organizational origins was captured by spin-off dummy variable, which takes the value of 1 for spin-off banks founded on the basis of one or more branches of a former Soviet state bank and the value of 0 for de novo banks created from scratch and not traceable to any of the former Soviet banks.

Regulatory regime shift. To test the effect of changes in the regulatory environment, we differentiated between the periods before and after the regulatory regime shift by using the dummy variable post-shift period, which takes the value of 0 for the years 1988-1995 and the value of 1 for the years 1996-2002. We include the year of the shift (1995) in the pre-shift period because the effects of the regulatory regime shift on survival would not be immediate.

Bank activities. To gauge the engagement in new activities by the restructuring spin-offs before the regulatory regime shift, we use two measures: (1) the number of foreign financial institutions with which the bank had correspondent accounts in 1994 (variable foreign correspondents) and (2) the share of loans to enterprises with private ownership in the bank's total loan portfolio at the end of 1994 (variable loans to private enterprises). The number of foreign correspondents indicates the extent of bank's involvement in international financial transactions, a novel activity for Russian banks, as they were not allowed to conduct any international operations prior to the fall of the "iron curtain." The proportion of loans to private enterprises in the bank's loan portfolio reflects the extent to which the spin-off banks switched from serving their traditional clientele of state enterprises to serving the clients from the emerging private sector. Working with private enterprises implied a new set of activities, associated with risk evaluation, monitoring of financial stability, and enforcement of loan agreements. To test whether engaging in the new activities before the regulatory regime shift 
affected the spin-offs' survival after the shift, we use two interaction variables: (1) foreign correspondents * spin-off and (2) loans to private enterprises * spin-off.

\section{Control Variables}

Competitive Environment. To control for the effects of the competitive environment, we use three variables: (1) contemporaneous competition intensity, calculated as the total number of commercial banks in a particular year divided by 100; (2) competition intensity squared; and (3) competition at founding, calculated as the number of banks in the year of founding divided by 100. To capture the linear effect of time on the hazard rate of liquidation we use variable industry age, specified as the number of years that elapsed since the birth of the industry in 1988 . We employ two dummy variables for location, Moscow and St. Petersburg, to control for the differences in the competitive environment between Russia's two largest cities and the rest of the country (Johnson, 2000).

Organizational Characteristics. We control for organizational size, measured by the bank's owned capital. An increase of the owned capital is a key indicator of the bank's growth, and the regulatory restrictions on different types of assets and liabilities are determined based on the bank's owned capital. We also include the variable organizational age as a control, measured as the number of years since founding. To control for the impact of foreign ownership, we use the respective dummy variable, which identifies banks with foreign shareholders. The descriptive statistics and the correlation matrix for all variables are presented in Table 1.

\section{--- INSERT TABLE 1 ABOUT HERE ---}

\section{Method of Estimation}

We estimated the effect of covariates on the hazard rate of liquidation by using survival analysis. Our initial examination demonstrated that the Weibull model provided better fit for the 
data than alternative models we tested, including Gompertz, exponential, lognormal, and loglogistic. The Weibull model defines baseline hazard $h_{0}$ as a function of time $t$ as follows:

$$
h_{0}(t)=\rho \lambda(\lambda t)^{\rho-1}
$$

where $\rho$ is a shape parameter estimated from the data and $\lambda$ is a scale parameter. This model can be generalized to include the effects of covariates:

$$
h\left(t_{j}\right)=h_{0}(t) g\left(x_{j}\right), \text { where } g\left(x_{j}\right)=\exp \left(x_{j} \beta\right)
$$

Depending on the value of $\rho$, the hazard rate may increase $(\rho>1)$, decrease $(0<\rho<1)$, or remain constant over time $(\rho=1)$. We estimate all the models using STATA.

\section{RESULTS}

To test Hypothesis 1 that spin-offs from restructured state enterprises are less likely to engage in new activities than de novo organizations, we assessed the banks' engagement in two new activities: international financial transactions and lending to private enterprises. Since the disclosure of information on foreign correspondent accounts and loan portfolio structure was not mandatory, not all banks reported this information and our analysis focused on 332 banks, for which the relevant data were available. As we expected, the banks disclosing non-mandatory information (including information on their activities) on average were larger compared with the population averages. We also found a higher proportion of Moscow banks among those disclosing information about their activities. To account for the possibility that organizational size and location may be related to the choice of activities, we controlled for these variables in our analysis.

To examine the effect of organizational origins on the propensity to provide international transaction services and to lend to private businesses, we regressed the variables "foreign correspondents" and "loans to private enterprises" on organizational origins while controlling 
for other important organizational characteristics. The results, presented in Table 2, show that tracing the origins to restructured state enterprises was negatively associated with opening foreign correspondent accounts and with lending to private enterprises. These findings provide support for Hypothesis 1.

\section{--- INSERT TABLE 2 ABOUT HERE ---}

To test Hypotheses 2, 3 and 4 that link the hazard of bank liquidation to bank origins and the regulatory regime shift, we conducted survival analysis on the entire population of banks founded in Russia since 1988. The results are reported in Table 3. To find out if spin-offs had survival advantages over de novo banks before the regulatory regime shift, we censored the observation period in 1995 and estimated the impact of spin-off origins on the hazard rate of liquidation for the 1988-1995 period (see Models 1 and 2 in Table 3). ${ }^{6}$ The coefficient for spinoff dummy is negative and significant, indicating the lower risk of liquidation for the spin-offs than for the de novo banks before the shift, as predicted by Hypothesis 2.

\section{--- INSERT TABLE 3 ABOUT HERE ---}

To test Hypothesis 3 that the mortality hazard for spin-offs would increase after the regulatory regime shift, we split our dataset into the subsets based on different origins (as suggested in the prior research, e.g., Swanson, 2002) and limited the analysis to the subpopulation of spin-off banks (see Models 3 and 4 in Table 3 ). ${ }^{7}$ The positive coefficient for the dummy variable post-shift period indicates that, during the post-shift (1996-2002) period, the spin-off banks experienced a higher risk of liquidation than during the pre-shift (1988-1995) period. This finding provides support for Hypothesis 3.

To test Hypothesis 4 that the impact of the regulatory regime shift should have a stronger negative effect on the survival of spin-offs than on the survival of de novo organizations, we 
conducted two sets of analysis. In the first set, we estimated the same models as in the analysis of spin-offs above, but this time for the de novo banks only (see Models 5 and 6 in Table 3) and then compared the results. A marginally significant negative effect of the post-shift period dummy on the hazard rate of liquidation of de novo banks (in Model 6) is in contrast to the significant positive effect of the post-shift period dummy on the hazard rate of liquidation of spin-off banks (in Model 4), leading us to conclude that the shift had a more detrimental effect on the survival of spin-off banks, as predicted by Hypothesis 4. Transforming the coefficients into hazard ratios (Cleves, Gould \& Gutierrez, 2004) reveals that before the regulatory regime shift the risk of liquidation for the de novo banks was three times higher than for the spin-offs and that the shift increased the risk for the spin-offs 2.7 times, while decreasing it for the de novo by 30 percent.

In the second set of analyses testing Hypothesis 4, we estimated the significance of interaction between spin-offs and post-shift period variables using the data for the full population over the entire observation period (see Models 7 and 8 in Table 3). Model 7 is the baseline model with dummies for the organizational origins (the variable spin-offs) and the regulatory regime shift (the variable post-shift period). This model demonstrates that, overall, the spin-offs had survival advantages vis-à-vis the de novo banks, and the hazard of liquidation after the shift was lower than before the shift. The period after the regulatory regime shift covers seven years, and, while the initial effect of the shift was disruptive, the regulatory changes introduced in 1995 and aimed at stabilizing the industry did eventually achieve the desired effect and led to the reduction in the hazard rate of liquidation. Model 8 adds the interaction variable spin-off*post-shift period. The significant positive coefficient for this variable indicates that, controlling for the main effect of organizational origins and the regulatory regime shift, the spin-offs were more adversely 
affected by the shift than the de novo. This result, obtained from the data for the full population of banks, is consistent with the earlier comparison of the effects of the regulatory regime shift on the de novo and the spin-off subpopulations, thus lending further support to Hypothesis 4.

The results for the control variables reflecting organizational characteristics in Table 3 show that organizational age, organizational size, and foreign ownership had consistently negative effect on the hazard rate of liquidation. The positive coefficient for Moscow indicates that the central location was associated with the higher hazard rate of liquidation. Moscow banks experienced particularly strong competition because more than 40 percent of all Russian banks were registered in Moscow. In the full population analysis (Models 7 and 8), the positive coefficients for competition intensity and competition at founding suggest that the hazard of liquidation increased as the result of more intense competition and that competitive conditions at the time of founding had a lasting effect on survival. The results of the subpopulation analyses (Models 3 through 6) suggest that the de novo banks were more adversely affected by intense competition than the spin-off banks: competition intensity, competition at founding, and Moscow location significantly increased the hazard rate for de novo, but not for spin-off banks. This is consistent with our argument that the spin-off banks served the established client base and, hence, were partly protected from competition.

We conducted a supplementary analysis to check whether the differences in the life chances between de novo and spin-off banks can be attributed to the differences in the resource endowments. We searched for data on endowment with financial resources at founding and were able to obtain archival data on the registered capital of banks as of May 1991. Since all banks were in operation for less than three years at that time, we used registered capital in 1991 as a proxy for the capital at founding. Our analysis of these data showed that there were no 
significant differences in the registered capital between de novo and spin-off banks. We replicated our test of Hypotheses 2, 3, and 4 with the added control for registered capital using data available for 1178 banks that were in operation by May 1991. The results obtained for this subpopulation were similar to the results obtained for the full population of 3068 banks as reported in Table 3. We also found that the registered capital in 1991 had a significant negative effect on the risk of failure during the pre-shift period. We can conclude that the initial resource endowments matter but the effects of organizational origins on survival cannot be explained by the initial resource endowments alone.

To test Hypothesis 5 that those spin-offs that engaged in the new activities before the shift would have survival advantages after the shift, we conducted the analysis with a sample of banks that operated at the end of 1994 (i.e., right before the regulatory regime shift) and examined the effects of various covariates on the survival of these banks after the shift. The results are provided in Table 4.

\section{--- INSERT TABLE 4 ABOUT HERE ---}

The results for our baseline model (Model 1) show no statistically significant difference between the spin-offs and the de novo banks in the hazard rate of liquidation after 1995. This indicates that, after the shift, the spin-offs no longer had survival advantages. The positive effect of organizational size on the risk of liquidation after 1995 may be attributed to the fact that large banks had a higher exposure to interbank and foreign currency loans and this made them especially vulnerable in the turbulent financial markets of the late 1990s. The negative effect of foreign ownership on liquidation after 1995 reflects the support provided by foreign investors to banks experiencing financial difficulties. The effect of competition intensity is relatively weak in this and subsequent models, which may be due to a decline in the total number of operating 
banks after 1995.

In Model 2 we added the three variables that reflect the proportion of loans allocated to three categories of borrowers: state enterprises, private enterprises, and individuals. In Model 3 we added a variable for the interaction between the organizational origins and the proportion of loans allocated to private enterprises (spin-off*loans to private enterprises). The coefficient for this interaction variable is negative and significant, indicating that, controlling for the main effects of organizational origins and loan portfolio structure, the spin-off banks with a larger proportion of loans allocated to private enterprises before the regulatory regime shift had better survival chances after the shift. In Model 4 we tested the effect of having foreign correspondent accounts and find that the spin-off banks that had more foreign correspondent accounts before the regulatory regime shift had a lower hazard of liquidation after the shift. Finally, Model 5 includes both interaction variables; the results are similar to those obtained in Models 3 and 4 for each interaction variable considered separately.

To test Hypothesis 6 that spin-offs from restructured state enterprises benefit more from engaging in new activities before the regulatory regime shift than do the de novo, we use margins analysis. The results of this analysis demonstrate that one standard deviation increase in the number of foreign correspondents has a significant negative effect on the risk of liquidation for restructuring spin-offs (Prob $>\chi^{2}=0.99$ ). Similarly, one standard deviation increase in the proportion of loans to private enterprises also has a significant negative effect on the risk of liquidation of restructuring spin-offs (Prob $>\chi^{2}=0.99$ ). In contrast, for the de novo, one standard deviation increase in the number of foreign correspondents does not have a statistically significant effect on the risk of liquidation (Prob $\left.>\chi^{2}=0.25\right)$ and the same holds for one standard deviation increase in the proportion of loans to private enterprises (Prob $>\chi^{2}=0.80$ ). These 
findings indicate that engaging in new activities before the regulatory regime shift was critical for the post-shift survival of restructuring spin-offs. In contrast, de novo organizations were able to adapt to a new regulatory regime even if they did not have extensive involvement in new activities before the regulatory regime shift.

\section{DISCUSSION AND CONCLUSIONS}

By building on the literature on prior shared experience (Fern et al., 2012; Kor, 2003; Reagans et al., 2005; Zheng, 2012), we have sought to explain how organizational origins (spinoffs versus de novo) affected the activities and survival of Russian banks. We found that spin-off banks had a tendency to engage in the activities that were similar to those performed by their parent organizations, whereas de novo banks were more likely to engage in the new activities. The tendency to engage in familiar activities contributed to the higher survival chances of the restructuring spin-offs vis-à-vis the de novo before the regulatory regime shift, but had a detrimental effect on the spin-offs' ability to adapt after the radical change in the regulatory environment. Some restructuring spin-offs, however, did engage in new activities before the shift and, as a result, fared better than other restructuring spin-offs after the shift. We also found that the positive effect of engaging in new activities before the regulatory regime shift on survival was more pronounced for the restructuring spin-offs than for de novo banks.

This study makes several important theoretical contributions. It demonstrates that prior shared experience may have both beneficial and detrimental implications. We rely on TMS theory to explain the impact of prior shared experience on activity choice and survival. While early research focused exclusively on TMS benefits, researchers have begun to acknowledge boundary conditions for deriving such benefits in more recent studies (Ren \& Argote, 2011). In particular, several studies have demonstrated that the value of TMS diminishes when teams or 
organizations have to perform a different task (Brandon \& Hollingshead, 2004; Edwards et al., 2006; Zheng, 2012). We suggest that TMS may also affect the choice of tasks to be performed (what we describe as a choice of activities) and organizations have a natural tendency to perform familiar tasks. This allows to maximize benefits from the existing TMS but has a detrimental effect on organizational ability to adapt to environmental changes that sooner or later force organizations to perform different tasks.

In their review of research on TMS, Ren and Argote expressed a conjecture that performance benefits of new ventures that were created from existing firms "are due to the operation of transactive memory systems that members developed in the parent firm." (2011: 222). We use this idea in our study to explain why pre-founding experience of spin-offs initially has a positive survival effect that, however, disappears over time (Carroll et al., 1996; Ganco \& Agarwal, 2009). The TMS perspective can also explain why prior shared experiences of team members would have different impact than individual experiences of founders. When separated from their teams, individuals would not be able to carry collective cognitive models with them the same way they carry individual expertise acquired in parent organizations.

The concept of TMS helps us to emphasize that collective experience of working together has the effect that goes beyond the effect of individual work experiences at state enterprises. In fact, some of the individuals with prior work experience in Soviet banks were also hired by de novo banks. What differentiated spin-off banks from de novo banks was extensive industryspecific prior shared experience (Fern et al., 2012; Zheng et al., 2016) of organizational members working together in the branches of a Soviet bank before these branches were converted into stand-alone spin-off banks. This transformation preserved TMS developed within branches of Soviet banks, thus enabling the re-enactment of familiar routines. This implies that 
prior shared work experience in state enterprises can strengthen the "legacy of the state" beyond the effect of individual experiences of employment in state enterprises.

By examining the survival of spin-offs from restructured state banks, we expand the scope of research on the survival implications of organizational origins. Studying spin-offs from state enterprises is important not only because they represent a sizeable portion of all spin-offs, especially in countries that have privatized their state assets, but also because spin-offs from restructured state enterprises are founded with different motivation compared with frequently studied entrepreneurial spin-offs (Parhankangas \& Arenius, 2003). A number of studies reported that entrepreneurial spin-offs have survival advantages over de novo start-ups (Agarwal et al., 2004; Klepper, 2009). However, the analysis of spin-offs from restructured state enterprises demonstrates that the survival advantages attributed in these past studies to pre-founding experience may be partially due to entrepreneurial intent to explore new business opportunities. Our findings suggest that, in the absence of an intent to explore new business opportunities, restructuring spin-offs exhibit a general tendency to pursue familiar activities that provide opportunities to leverage what they inherited from their parent organizations.

We demonstrate the effects of pre-founding experience that have not been described in prior studies and would not be anticipated based on the existing literature. Some researchers argue that organizations with pre-founding experience are better prepared to deal with environmental turbulence (Chen et al., 2012; Ganco \& Agarwal, 2009) but others suggest that “institutional upheaval” would be particularly damaging for institutionally-embedded organizations that would have to unlearn inappropriate capabilities (Newman, 2000). We find that spin-offs from state banks were able to adapt successfully to the turbulence associated with market liberalization in the early 1990s, but have difficulties adapting to new rules of the game 
introduced as the next step of the market reforms. We also show that restructuring spin-offs benefit more than de novo organizations from engaging in new activities before the regulatory regime shift. Although the importance of new activities in organizational adaptation to different environmental conditions has been acknowledged in prior research already, we suggest that engaging in new activities is more important for boosting adaptive capacity when organizational members have extensive prior shared experience.

By focusing on organizations originating from state enterprises, our study contributes to the literature on market reforms (Filatotchev et al., 2003; Lyles et al., 2004; Tihanyi \& Hegarty, 2007; Yiu, Hoskisson, Bruton, \& Lu, 2014; Zahra et al., 2000) and, in particular, to the debate about the relative importance of de novo and privatized enterprises in the process of revitalizing former state-controlled economies (Estrin et al., 2005; Wachtel, 1999). The overwhelming majority of research on market reforms focused on the effect of privatization and compared performance of privatized companies and those remaining under state control (Djankov \& Murrell, 2002; Megginson \& Netter, 2001). At the same time, few studies compared the performance of privatized companies with the performance of new ventures (D'Souza et al., 2017). Our study demonstrates that, on average, restructuring spin-offs are much less entrepreneurial than de novo organizations even though engaging in new activities can significantly boost their long-term survival chances.

Our findings also contribute to the relatively unexplored area of the survival outcomes of institutional entrepreneurship (Pacheco et al., 2010). If we consider the engagement in new activities prior to the regulatory shift as an instance of institutional entrepreneurship, such as the initiation or active implementation of changes that diverge from existing institutions (Battilana, Leca, \& Boxenbaum, 2009), then our findings for de novo organizations reveal the risks of 
institutional entrepreneurship. At the same time, our results suggest that institutional entrepreneurship may bring long-term survival benefits for the incumbents (restructuring spinoffs), reflecting the advantages of organizational hybridization (Battilana, Besharov, \& Mitzinneck, 2017). Organizational hybrids combine elements of different institutional orders; this reflects and fosters their adaptation to competing environmental demands. For restructuring spin-offs, combining traditional and new activities before the regime shift would indicate an underlying "structured flexibility" (Smith \& Besharov, 2018) in dealing with environmental complexity that can enhance survival chances.

One limitation of our study is that we explored relatively few activities. Another limitation is that we did not study systematically the factors that may predict which restructuring spin-offs are more likely to overcome the inertia associated with the inherited organizational routines and to engage in new activities. How the characteristics of restructuring spin-offs impact their choice of activities is a question for further research. Another question for future research is whether the pattern observed in our study is likely to be found in the context of different types of environmental changes. In such closely regulated industry as banking, organizations are deeply affected by radical changes in the regulatory environment (Tihanyi \& Hegarty, 2007). In comparison, a less regulated industry may be more affected by a technological revolution that causes a "competence-destroying discontinuity" (Tushman \& Anderson, 1986). Future research is needed to test whether our hypotheses hold for radical changes in business environment produced by technological revolutions or political uprisings. Finally, it would be important to study the dynamics of TMS in spin-off organizations at the micro-level to explore how TMS are affected by separation from a parent organization and by engagement in new activities.

In conclusion, the ability of organizations to respond to changing market conditions is 
considered essential for their survival. Yet, if an organization only acts in response to an environmental change, it will lag behind those of its rivals that start experimenting with new activities before the need for change becomes evident. Engaging in proactive experimentation with new activities is challenging because the constraining effect of prior experience and because the return on the familiar activities is often higher than the return on the new activities. With the appeal of focusing on familiar activities and the uncertainty surrounding the timing of an environmental shift, many organizations are caught unprepared to deal with environmental changes. The findings of this study suggest that the ability of organizations to successfully adapt to environmental changes is rooted in proactive experimentation with new activities and such experimentation is particularly critical for organizations originating from state enterprises. 


\section{REFERENCES}

Abarbanell, J. S., \& Meyendorff, A. 1997. Bank privatization in post-communist Russia: The case of Zhilsotsbank. Journal of Comparative Economics, 25: 62-96.

Agarwal, R., Campbell, B. A., Franco, A. M., \& Ganco, M. 2016. What do I take with me? The mediating effect of spin-out team size and tenure on the founder-firm performance relationships. Academy of Management Journal, 59: 1060-1087.

Agarwal, R., Echambadi, R., Franco, A. M., \& Sarkar, M. B. 2004. Knowledge transfer through inheritance: Spin-out generation, development, and survival. Academy of Management Journal, 47: 501-522.

Argote, L., \& Guo, J. M. 2016. Routines and transactive memory systems: Creating, coordinating, retaining, and transferring knowledge in organizations. Research in Organizational Behavior, 36: $65-84$.

Argote, L., \& Ren, Y. 2012. Transactive memory systems: A microfoundations of dynamic capabilities. Journal of Management Studies, 49: 1375-1382.

Autio, E., George, G., \& Alexy, O. 2011. International entrepreneurship and capability development - qualitative evidence and future research directions. Entrepreneurship Theory and Practice, 35: 11-37.

Barisitz, S. 2004. Distorted incentives fading? The evolution of the Russian banking sector since perestroika. Oesterreichische Nationalbank. Focus on European Economic Integration (2004/01): 122-152.

Barnett, W. P., Greve, H. R., \& Park, D. Y. 1994. An evolutionary model of organizational performance. Strategic Management Journal, 15(S1): 11-28.

Battilana, J., Besharov, M. L., \& Mitzinneck, B. C. 2017. On hybrids and hybrid organizing: A review and roadmap for future resarch. In R. Greenwood, C. Oliver, R. Suddaby and K. Sahlin-Andersson (Eds.), The Sage Handbook of Organizational Institutionalism: 132-169. Thousand Oaks, CA: Sage.

Battilana, J., Leca, B., \& Boxenbaum, E. 2009. How actors change institutions: Towards a theory of institutional entrepreneurship. Academy of Management Annals, 3: 65-107.

Bayus, B. L., \& Agarwal, R. 2007. The role of pre-entry experience, entry timing, and product technology strategies in explaining firm survival. Management Science, 53: 1887-1902.

Becker, M. C. 2004. Organizational routines: A review of the literature. Industrial and Corporate Change, 13: 643-677.

Beckman, C. M. 2006. The influence of founding team company affiliations on firm behavior. Academy of Management Journal, 49: 741-758.

Benner, M. J., \& Tushman, M. L. 2003. Exploitation, exploration, and process management: The productivity dilemma revisited. Academy of Management Review, 28: 283-256.

Berman, S. L., Down, J., \& Hill, C. W. L. 2002. Tacit knowledge as a source of competitive advantage in the national basketball association. Academy of Management Journal, 45: 13-31.

Boycko, M., Shleifer, A., \& Vishny, R. 1994. Privatizing Russia. Cambridge, MA: MIT Press.

Bradley, S. W., Aldrich, H., Shepherd, D. A., \& Wiklund, J. 2011. Resources, environmental change, and survival: Asymmetric paths of young independent and subsidiary organizations. Strategic Management Journal, 32: 486-509.

Brandon, D. P., \& Hollingshead, A. B. 2004. Transactive memory systems in organizations: Matching tasks, expertise, and people. Organization Science, 15: 633-644.

Bryant, P. T. 2014. Imprinting by design: The microfoundations of entrepreneurial adaptation. 
Entrepreneurship Theory and Practice, 38: 1081-1102.

Burgelman, R. A. 2002. Strategy as vector and the inertia of coevolutionary lock-in. Administrative Science Quarterly, 47: 325-357.

Campbell, B. A., Ganco, M., Franco, A. M., \& Agarwal, R. 2012. Who leaves, where to, and why worry? Employee mobility, entrepreneurship and effects on source firm performance. Strategic Management Journal, 33: 65-87.

Carroll, G. R., Bigelow, L. S., Seidel, M. L., \& Tsai, L. B. 1996. The fates of de novo and de alio producers in the American automobile industry, 1885-1981. Strategic Management Journal, 17: 117-137.

Chen, P.-L., Williams, C., \& Agarwal, R. 2012. Growing pains: Pre-entry experience and the challenge of transition to incumbency. Strategic Management Journal, 33: 252-276.

Cho, T., \& Shen, W. 2007. Changes in executive compensation following an environmental shift: The role of top management team turnover. Strategic Management Journal, 28: 747-754.

Cleves, M. A., Gould, W. W., \& Gutierrez, R. G. 2004. An Introduction to Survival Analysis Using Stata. College Station, TX: Stata Press.

D’Souza, J., Megginson, W. L., Ullah, B., \& Wei, Z. 2017. Growth and growth obstacles in transition economies: Privatized versus de novo private firms. Journal of Corporate Finance, 42: 422-438.

Dencker, J. C., \& Gruber, M. 2015. The effects of opportunities and founder experience on new firm performance. Strategic Management Journal, 36: 1035-1052.

Dencker, J. C., Gruber, M., \& Shah, S. K. 2009. Pre-entry knowledge, learning, and the survival of new firms. Organization Science, 20: 516-537.

Djankov, S., \& Murrell, P. 2002. Enterprise restructuring in transition: A quantitative survey. Journal of Economic Literature, 40: 739-792.

Edwards, B. D., Day, E. A., Arthur, W., \& Bell, S. T. 2006. Relationships among team ability composition, team mental models, and team performance. Journal of Applied Psychology, 91: 727-736.

Eisenhardt, K. M., \& Schoonhoven, C. B. 1990. Organizational growth: Linking founding team, strategy, environment, and growth among U.S. semiconductor ventures, 1978-1988. Administrative Science Quarterly, 35: 504-529.

Estrin, S., Meyer, K., \& Bytchkova, M. 2005. Entrepreneurship in transition economies. In M. Casson, B. Yeung, A. Basu and N. Wadeson (Eds.), The Oxford Handbook of Entrepreneurship: Oxford University Press.

Fern, M. J., Cardinal, L. B., \& O'Neill, H. M. 2012. The genesis of strategy in new ventures: Escaping the constraints of founder and team knowledge. Strategic Management Journal, 33: 427-447.

Filatotchev, I., Buck, T., \& Wright, M. 1992. Privatisation and entrepreneurship in the break-up of the USSR. World Economy, 15: 505-524.

Filatotchev, I., Buck, T., \& Zhukov, V. 2000. Downsizing in privatized firms in Russia, Ukraine and Belarus. Academy of Management Journal, 43: 286-304.

Filatotchev, I., Wright, M., Ullenbruck, K., Tihanyi, L., \& Hoskisson, R. 2003. Governance, organizational capabilities, and restructuring in transition economies. Journal of World Business, 38: 331-347.

Fortune, A., \& Mitchell, W. 2012. Unpacking firm exit at the firm and industry levels: The adaptation and selection of firm capabilities. Strategic Management Journal, 33: 794-819.

Furr, N. R., Cavarretta, F., \& Garg, S. 2012. Who changes course? The role of domain knowledge 
and novel framing in making technology changes. Strategic Entrepreneurship Journal, 6: 236-256.

Ganco, M. 2013. Cutting the Gordian knot: The effect of knowledge complexity on employee mobility and entrepreneurship. Strategic Management Journal, 34: 666-686.

Ganco, M., \& Agarwal, R. 2009. Performance differentials between diversifying entrants and entrepreneurial start-ups: A complexity approach. Academy of Management Review, 34: 228252.

Geroski, P. A., Mata, J., \& Portugal, P. 2010. Founding conditions and the survival of new firms. Strategic Management Journal, 31: 510-529.

Haveman, H. A., Russo, M., \& Meyer, A. D. 2001. Organizational environments in flux: The impact of regulatory punctuations on organizational domains, CEO succession, and performance. Organization Science, 12: 253-273.

Hecker, A. 2012. Knowledge beyond the individual? Making sense of a notion of collective knowledge in organization theory. Organization Studies, 33: 423-445.

Helfat, C. E., \& Lieberman, M. B. 2002. The birth of capabilities: Market entry and the importance of pre-history. Industrial and Corporate Change, 11: 725-760.

Johnson, J. 2000. A fistful of rubles: The rise and fall of the Russian banking system. Ithaca and London, UK: Cornell University Press.

Khessina, O. M. 2003. Entry mode, technological innovation and firm survival in the worldwide optical disk drive industry, 1983-1999. Unpublished Ph.D. Thesis, University of California, Berkeley, CA

Klepper, S. 2009. Spinoffs: A review and synthesis. European Management Review, 6: 159-171.

Klepper, S., \& Sleeper, S. 2005. Entry by spinoffs. Management Science, 51: 1291-1306.

Klimoski, R., \& Mohammed, S. 1994. Team mental model: Construct or metaphor? Journal of Management, 20: 403-437.

Kogut, B., \& Spicer, A. 2002. Capital market development and mass privatization are logical contradictions: Lessons from Russia and the Czech Republic. Industrial and Corporate Change, 11: 1-37.

Kor, Y. Y. 2003. Experience-based top management team competence and sustained growth. Organization Science, 14: 707-719.

Levitt, B., \& March, J. G. 1988. Organizational learning. Annual Review of Sociology, 14: 319340.

Lewis, K., Lange, D., \& Gillis, L. 2005. Transactive memory systems, learning, and learning transfer. Organization Science, 16: 581-598.

Liang, D. W., Moreland, R., \& Argote, L. 1995. Group versus individual training and group performance: The mediating role of transactive memory. Personality and Social Psychology Bulletin, 21: 384-393.

Lyles, M. A., Saxton, T., \& Watson, K. 2004. Venture survival in a transitional economy. Journal of Management, 30: 351-375.

Mathieu, J. E., Heffner, T. S., Goodwin, G. F., Salas, E., \& Cannon-Bowers, J. A. 2000. The influence of shared mental models on team process and performance. Journal of Applied Psychology, 85: 273-283.

Megginson, W. L., \& Netter, J. M. 2001. From state to market: A survey of empirical studies on privatization. Journal of Economic Literature, 39: 321-389.

Miller, K. D., Choi, S., \& Pentland, B. T. 2014. The role of transactive memory in the formation of organizational routines. Strategic Organization, 12: 109-133. 
Mitchell, W. 1994. The dynamics of evolving markets: The effects of business sales and age on dissolutions and divestitures. Administrative Science Quarterly, 39: 575-602.

Mohammed, S., Ferzandi, L., \& Hamilton, K. 2010. Metaphor no more: A 15-year review of the team mental model construct. Journal of Management, 36: 876-910.

Narayanan, V. K., Yang, Y., \& Zahra, S. A. 2009. Corporate venturing and value creation: A review and proposed framework. Research Policy, 38: 58-76.

Nelson, R. R., \& Winter, S. G. 1982. An Evolutionary Theory of Economic Change. Cambridge, MA: Harvard University Press.

Newman, K. L. 2000. Organizational transformation during institutional upheaval. Academy of Management Review, 25: 602-619.

Oertel, S., Thommes, K., \& Walgenbach, P. 2016. Organizational failure in the aftermath of radical institutional change. Organization Studies, 37: 1067-1087.

Pacheco, D. F., York, J. G., Dean, T. J., \& Sarasvathy, S. D. 2010. The coevolution of institutional entrepreneurship: A tale of two theories. Journal of Management, 36: 974-1010.

Parhankangas, A., \& Arenius, P. 2003. From a corporate venture to an independent company: A base for a taxonomy for corporate spin-off firms. Research Policy, 32: 463-481.

Peltokorpi, V. 2008. Transactive memory systems. Review of General Psychology, 12: 378-394.

Penrose, E. T. 1959. The theory of the growth of the firm. New York: John Wiley.

Phillips, D. J. 2002. A genealogical approach to organizational life chances: The parent-progeny transfer among Silicon Valley law firms, 1946-1996. Administrative Science Quarterly, 47: 474-506.

Reagans, R., Argote, L., \& Brooks, D. 2005. Individual experience and experience working together: Predicting learning rates from knowing who knows what and knowing how to work together. Management Science, 51: 869-881.

Ren, Y., \& Argote, L. 2011. Transactive memory systems 1985-2010. Academy of Management Annals, 5: 189-229.

Ren, Y., Carley, K. M., \& Argote, L. 2006. The contingent effects of transactive memory: When is it more beneficial to know what others know? Management Science, 52: 671-682.

Sedaitis, J. 1998. The alliances of spin-offs versus start-ups: Social ties in the genesis of postSoviet alliances. Organization Science, 9: 368-381.

Shane, S., \& Stuart, T. 2002. Organizational endowments and the performance of university startups. Management Science, 48: 154-170.

Sine, W. D., \& David, R. J. 2003. Environmental jolts, institutional change, and the creation of entrepreneural opportunity in the US electric power industry. Research Policy, 32: 185-207.

Smith, W. K., \& Besharov, M. 2018. Bowing before dual gods: how structured flexibility sustains organizational hybridity. Administrative Science Quarterly, forthcoming.

Spicer, A., McDermott, G. A., \& Kogut, B. 2000. Entrepreneurship and privatization in Central Europe: The tenuous balance between destruction and creation. Academy of Management Review, 25: 630-649.

Suhomlinova, O. 1999. Constructive destruction: Transformation of Russian state-owned construction enterprises during market transition. Organization Studies, 20: 451-484.

Swanson, A. N. 2002. Form coherence and the fates of de alio and de novo organizations in the U.S. digital computer industry: 1951-1994. Unpublished PhD thesis, Stanford University

Tihanyi, L., \& Hegarty, W. H. 2007. Political interests and the emergence of commercial banking in transition economies. Journal of Management Studies, 44: 788-813.

Tushman, M. L., \& Anderson, P. 1986. Technological discontinuities and organizational 
environments. Administrative Science Quarterly, 31: 439-465.

Wachtel, P. 1999. Entrepreneurship in the transition economies of Central and Eastern Europe. Journal of Business Venturing, 14: 417-425.

Wegner, D. M. 1987. Transactive memory: A contemporary analysis of the group mind. In B. Mullen and G. R. Goethals (Eds.), Theories of group behavior: 185-208. New York: Springer.

Wezel, F. C., Cattani, G., \& Pennings, J. M. 2006. Competitive implications of interfirm mobility. Organization Science, 17: 691-709.

Wheelock, D. C., \& Wilson, P. W. 2000. Why do banks disappear? The determinants of U.S. bank failures and acquisitions. Review of Economics and Statistics, 82: 127-138.

Woolley, J. L. 2017. Origins and outcomes: The roles of spin-off founders and intellectual property in high-technology venture outcomes. Academy of Management Discoveries, 3: 6490.

Xu, K., Laszlo, T., \& Hitt, M. A. 2017. Firm resources, governmental power, and privatization. Journal of Management, 43: 998-1024.

Yiu, D., Bruton, G. D., \& Lu, Y. 2005. Understanding business group performance in an emerging economy: Acquiring resources and capabilities in order to prosper. Journal of Management Studies, 42: 183-206.

Yiu, D., Hoskisson, R. E., Bruton, G. D., \& Lu, Y. 2014. Dueling institutional logics and the effect on strategic entrepreneurship in Chinese business groups. Strategic Entrepreneurship Journal, 8: 195-213.

Zahra, S. A., Ireland, R. D., Gutierrez, I., \& Hitt, M. A. 2000. Privatization and entrepreneurial transformation: Emerging issues and a future research agenda. Academy of Management Review, 25: 509-524.

Zheng, Y. 2012. Unlocking founding team prior shared experience: A transactive memory system perspective. Journal of Business Venturing, 27: 577-591.

Zheng, Y., Devaughn, M. L., \& Zellmer-Bruhn, M. 2016. Shared and shared alike? Founders' prior shared experience and performance of newly founded banks. Strategic Management Journal, 37: 2503-2520.

Zheng, Y., \& Mai, Y. 2013. A contextualized transactive memory system view on how founding teams respond to surprises: Evidence from China. Strategic Entrepreneurship Journal, 7: 197213.

Zollo, M., \& Winter, S. G. 2002. Deliberate learning and the evolution of dynamic capabilities. Organization Science, 13: 339-351. 


\section{NOTES}

${ }^{1}$ While we focus on restructuring that results in creating spin-offs, other forms of restructuring have been described in market transition studies including downsizing, changing product portfolios, and creating business groups (Filatotchev et al., 2000; Filatotchev et al., 2003; Yiu, Bruton, \& Lu, 2005).

${ }^{2}$ When considering changes in the environmental conditions, it is important to distinguish between an environmental shift (Cho \& Shen, 2007) and an environmental jolt (Sine \& David, 2003). A shift implies that the environmental conditions permanently change, while a jolt refers to some temporary disturbance after which the pre-disturbance environmental conditions can be restored.

${ }^{3}$ Notice that for the purpose of this study, we define new activities as activities that are new for the industry rather than for a particular organization.

${ }^{4}$ During the 1990s, the Russian banking industry experienced several major crises, including those caused by the rouble devaluation in October 1994 and by the government default on its bonds in August 1998. These crises contributed to a high turnover in the industry ranks and attracted extensive media attention, but they did not have a profound impact on how banks operated. In contrast, the fundamental changes in economic policies and industry regulation that occurred in 1995, while being less noticeable to the general public, redefined the "rules of the game" and had lasting consequences for the industry.

${ }^{5}$ Our focus on survival as an outcome variable has a number of advantages. First, over the years, a number of studies focused on the effect organizational origins on survival and we can evaluate the findings of our study relative to this body of literature. Second, other organizational outcomes, such as financial performance, would be affected by idiosyncratic characteristics of policies that regulated financial reporting in the Russian banking industry. Third, our focus on survival ensures that we have comprehensive and reliable data, which would not be affected by the problem of missing financial reports and by tax avoidance tactics.

${ }^{6}$ By terminating our analysis period earlier, we do not introduce biases in our analysis (as would be the case if we were to start our analysis period after 1988 thus creating left truncation).

${ }^{7}$ Note that the de novo banks were still included in the count for the competition intensity variables. We did, however, remove the control variable industry age to avoid collinearity, because all spin-off banks had been founded in the early 1990s and their organizational age was thus highly correlated with the industry age. 
Table 1

Descriptive Statistics and Correlations ${ }^{a}$

\begin{tabular}{|c|c|c|c|c|c|c|c|c|c|c|c|c|c|c|c|c|c|c|}
\hline & & Mean & SD & 1 & 2 & 3 & 4 & 5 & 6 & 7 & 8 & 9 & 10 & 11 & 12 & 13 & 14 & 15 \\
\hline 1 & Competition intensity & 18.88 & 5.13 & & & & & & & & & & & & & & & \\
\hline 2 & $\begin{array}{l}\text { Competition intensity } \\
\text { squared }\end{array}$ & 382.81 & 186.62 & 0.99 & & & & & & & & & & & & & & \\
\hline 3 & $\begin{array}{l}\text { Competition at } \\
\text { founding }\end{array}$ & 15.77 & 7.29 & 0.17 & 0.14 & & & & & & & & & & & & & \\
\hline 4 & Industry age & 8.86 & 3.34 & -0.20 & -0.26 & 0.36 & & & & & & & & & & & & \\
\hline 5 & Organizational size & 0.27 & 0.23 & -0.07 & -0.08 & 0.15 & 0.21 & & & & & & & & & & & \\
\hline 6 & Organizational age & 3.98 & 3.11 & -0.26 & -0.31 & -0.16 & 0.82 & 0.12 & & & & & & & & & & \\
\hline 7 & Moscow & 0.38 & 0.49 & 0.01 & 0.01 & 0.29 & 0.17 & 0.32 & -0.01 & & & & & & & & & \\
\hline 8 & St Petersburg & 0.03 & 0.16 & -0.02 & -0.01 & -0.01 & 0.02 & -0.02 & 0.02 & -0.13 & & & & & & & & \\
\hline 9 & Foreign ownership & 0.08 & 0.27 & -0.05 & -0.05 & -0.03 & 0.08 & 0.26 & 0.09 & 0.15 & 0.03 & & & & & & & \\
\hline 10 & Spin-off & 0.27 & 0.44 & -0.10 & -0.10 & -0.51 & -0.21 & -0.18 & 0.08 & -0.40 & -0.08 & -0.08 & & & & & & \\
\hline 11 & Post-shift period & 0.51 & 0.50 & -0.29 & -0.36 & 0.28 & 0.84 & 0.18 & 0.70 & 0.14 & 0.02 & 0.07 & -0.16 & & & & & \\
\hline 12 & $\begin{array}{l}\text { Spin-off } * \text { Post-shift } \\
\text { period }\end{array}$ & 0.10 & 0.30 & -0.08 & -0.10 & -0.28 & 0.26 & -0.06 & 0.45 & -0.21 & -0.04 & -0.02 & 0.55 & 0.33 & & & & \\
\hline 13 & Loans to SOEs & 25.75 & 24.95 & -0.03 & -0.03 & -0.10 & 0.02 & 0.00 & 0.05 & -0.25 & -0.04 & 0.00 & 0.23 & 0.02 & 0.14 & & & \\
\hline 14 & $\begin{array}{l}\text { Loans to private } \\
\text { enterprises }\end{array}$ & 59.88 & 27.92 & 0.02 & 0.03 & 0.08 & 0.00 & 0.07 & -0.03 & 0.25 & 0.05 & 0.00 & -0.25 & -0.01 & -0.14 & -0.76 & & \\
\hline 15 & Loans to individuals & 7.66 & 10.50 & 0.04 & 0.03 & 0.10 & -0.01 & -0.19 & -0.04 & -0.21 & -0.01 & -0.09 & 0.08 & -0.01 & 0.02 & -0.16 & -0.17 & \\
\hline 16 & Foreign correspondents & 6.18 & 10.95 & -0.05 & -0.04 & -0.25 & -0.05 & 0.26 & 0.04 & 0.13 & 0.09 & 0.27 & -0.07 & -0.03 & -0.03 & -0.01 & 0.01 & -0.13 \\
\hline
\end{tabular}

${ }^{\mathrm{a}}$ Correlations above .03 and below -.03 are significant at $\mathrm{p}<.05$ 
Table 2

The Effects of Bank Origins on Foreign Correspondent Accounts and Loans to Private Enterprises as of the End of 1994 a

\begin{tabular}{|c|c|c|c|c|}
\hline \multirow[b]{2}{*}{ Variables } & \multicolumn{2}{|c|}{ Loans to private enterprises } & \multicolumn{2}{|c|}{ Foreign correspondents } \\
\hline & Model 1 & Model 2 & Model 3 & Model 4 \\
\hline Registered capital & $\begin{array}{l}-1.96 \\
(1.52)\end{array}$ & $\begin{array}{l}-0.83 \\
(1.56)\end{array}$ & $\begin{array}{c}2.15^{* *} \\
(0.52)\end{array}$ & $\begin{array}{c}2.57 * * \\
(0.53)\end{array}$ \\
\hline St Petersburg & $\begin{array}{c}12.05 \\
(10.14)\end{array}$ & $\begin{array}{c}5.07 \\
(10.36)\end{array}$ & $\begin{array}{c}5.52 \\
(2.98)\end{array}$ & $\begin{array}{c}2.98 \\
(3.06)\end{array}$ \\
\hline Moscow & $\begin{array}{c}13.59 * * \\
(3.85)\end{array}$ & $\begin{array}{c}6.78 \\
(4.60)\end{array}$ & $\begin{array}{c}3.51^{* *} \\
(1.30)\end{array}$ & $\begin{array}{c}0.93 \\
(1.54)\end{array}$ \\
\hline Number of branches & $\begin{array}{c}-0.54 * \\
(0.26)\end{array}$ & $\begin{array}{l}-0.50 \\
(0.26)\end{array}$ & $\begin{array}{c}0.24^{* *} \\
(0.09)\end{array}$ & $\begin{array}{c}0.27^{* *} \\
(0.09)\end{array}$ \\
\hline Foreign ownership & $\begin{array}{l}-1.70 \\
(5.22)\end{array}$ & $\begin{array}{l}-1.58 \\
(5.16)\end{array}$ & $\begin{array}{c}6.65^{* *} \\
(1.72)\end{array}$ & $\begin{array}{c}6.57^{* *} \\
(1.70)\end{array}$ \\
\hline Spin-off & & $\begin{array}{c}-10.99 * * \\
(4.18)\end{array}$ & & $\begin{array}{c}-4.29 * * \\
(1.42)\end{array}$ \\
\hline Constant & $\begin{array}{c}60.21 * * \\
(3.85)\end{array}$ & $\begin{array}{c}54.50^{* *} \\
(4.38)\end{array}$ & $\begin{array}{l}-2.12 \\
(1.30)\end{array}$ & $\begin{array}{c}-4.35^{* *} \\
(1.48)\end{array}$ \\
\hline $\mathrm{R}$ sq. & 0.10 & 0.13 & 0.25 & 0.28 \\
\hline
\end{tabular}

\footnotetext{
${ }^{a}$ Standard errors are shown in parentheses, $\mathrm{N}=308$.
}

$* \mathrm{p}<0.05$

$* * \mathrm{p}<0.01$ 
Table 3 Maximum Likelihood Estimates of Organizational Mortality for the Russian Banks a

\begin{tabular}{|c|c|c|c|c|c|c|c|c|}
\hline & \multicolumn{2}{|c|}{ 1988-1995, all banks } & \multicolumn{2}{|c|}{ 1988-2002, spin-offs only } & \multicolumn{2}{|c|}{ 1988-2002, de novo only } & \multicolumn{2}{|c|}{ 1988-2002, all banks } \\
\hline & Model 1 & Model 2 & Model 3 & Model 4 & Model 5 & Model 6 & Model 7 & Model 8 \\
\hline Competition intensity & $\begin{array}{l}-0.55 \\
(0.38)\end{array}$ & $\begin{array}{l}-0.32 \\
(0.41)\end{array}$ & $\begin{array}{l}-2.71 * * \\
(0.37)\end{array}$ & $\begin{array}{l}-3.50^{* *} \\
(0.52)\end{array}$ & $\begin{array}{l}0.41 * * \\
(0.11)\end{array}$ & $\begin{array}{l}0.70^{* *} \\
(0.18)\end{array}$ & $\begin{array}{l}1.11 * * \\
(0.16)\end{array}$ & $\begin{array}{l}1.09 * * \\
(0.16)\end{array}$ \\
\hline $\begin{array}{l}\text { Competition intensity } \\
\text { squared }\end{array}$ & $\begin{array}{l}0.01 \\
(0.01)\end{array}$ & $\begin{array}{l}0.01 \\
(0.01)\end{array}$ & $\begin{array}{l}0.03^{* *} \\
(0.01)\end{array}$ & $\begin{array}{l}0.05^{* *} \\
(0.01)\end{array}$ & $\begin{array}{l}-0.01 * * \\
(0.00)\end{array}$ & $\begin{array}{l}-0.01 * * \\
(0.00)\end{array}$ & $\begin{array}{l}-0.03 * * \\
(0.00)\end{array}$ & $\begin{array}{l}-0.03 * * \\
(0.00)\end{array}$ \\
\hline Competition at founding & $\begin{array}{l}-0.69 * * \\
(0.09)\end{array}$ & $\begin{array}{l}-0.62 * * \\
(0.08)\end{array}$ & $\begin{array}{l}-0.76^{* *} \\
(0.07)\end{array}$ & $\begin{array}{l}-0.82 * * \\
(0.07)\end{array}$ & $\begin{array}{l}0.06^{* *} \\
(0.02)\end{array}$ & $\begin{array}{l}0.07 * * \\
(0.02)\end{array}$ & $\begin{array}{l}0.06 * * \\
(0.02)\end{array}$ & $\begin{array}{l}0.09 * * \\
(0.02)\end{array}$ \\
\hline Industry age & $\begin{array}{l}4.39 * * \\
(0.42)\end{array}$ & $\begin{array}{l}3.87 * * \\
(0.41)\end{array}$ & & & $\begin{array}{l}-0.01 \\
(0.09)\end{array}$ & $\begin{array}{l}0.07 \\
(0.10)\end{array}$ & $\begin{array}{r}0.06 \\
(0.10)\end{array}$ & $\begin{array}{r}0.01 \\
(0.10)\end{array}$ \\
\hline Organizational size & $\begin{array}{l}-59.94^{* *} \\
(6.26)\end{array}$ & $\begin{array}{l}-59.06^{* *} \\
(6.26)\end{array}$ & $\begin{array}{l}-22.27^{* *} \\
(2.54)\end{array}$ & $\begin{array}{l}-22.35^{* *} \\
(2.55)\end{array}$ & $\begin{array}{l}-14.57^{* *} \\
(0.84)\end{array}$ & $\begin{array}{l}-14.54^{* *} \\
(0.84)\end{array}$ & $\begin{array}{l}-15.99 * * \\
(0.82)\end{array}$ & $\begin{array}{l}-15.80 * * \\
(0.81)\end{array}$ \\
\hline Organizational age & $\begin{array}{l}-9.75^{* *} \\
(0.58)\end{array}$ & $\begin{array}{l}-9.16^{* *} \\
(0.57)\end{array}$ & $\begin{array}{l}-15.49^{* *} \\
(0.88)\end{array}$ & $\begin{array}{l}-15.81 * * \\
(0.89)\end{array}$ & $\begin{array}{l}-2.87 * * \\
(0.13)\end{array}$ & $\begin{array}{l}-2.86^{* *} \\
(0.13)\end{array}$ & $\begin{array}{l}-2.70 * * \\
(0.12)\end{array}$ & $\begin{array}{l}-2.79 * * \\
(0.12)\end{array}$ \\
\hline Moscow & $\begin{array}{l}0.65^{* *} \\
(0.12)\end{array}$ & $\begin{array}{l}0.43^{* *} \\
(0.12)\end{array}$ & $\begin{array}{l}0.37 \\
(0.27)\end{array}$ & $\begin{array}{l}0.38 \\
(0.27)\end{array}$ & $\begin{array}{l}0.31 * * \\
(0.06)\end{array}$ & $\begin{array}{l}0.31^{* *} \\
(0.06)\end{array}$ & $\begin{array}{l}0.33 * * \\
(0.06)\end{array}$ & $\begin{array}{l}0.31 * * \\
(0.06)\end{array}$ \\
\hline St Petersburg & $\begin{array}{l}-0.31 \\
(0.51)\end{array}$ & $\begin{array}{l}-0.57 \\
(0.51)\end{array}$ & $\begin{array}{l}-24.72 \\
(22624)\end{array}$ & $\begin{array}{l}-23.59 \\
(12891)\end{array}$ & $\begin{array}{l}-0.41 \\
(0.21)\end{array}$ & $\begin{array}{l}-0.41 \\
(0.21)\end{array}$ & $\begin{array}{l}-0.42 * \\
(0.21)\end{array}$ & $\begin{array}{l}-0.43 * \\
(0.21)\end{array}$ \\
\hline Foreign ownership & $\begin{array}{l}-14.57 \\
(985.42)\end{array}$ & $\begin{array}{l}-14.03 \\
(684.61)\end{array}$ & $\begin{array}{l}0.41 \\
(0.60)\end{array}$ & $\begin{array}{l}0.41 \\
(0.60)\end{array}$ & $\begin{array}{l}-0.86^{* *} \\
(0.23)\end{array}$ & $\begin{array}{l}-0.86^{* *} \\
(0.23)\end{array}$ & $\begin{array}{l}-0.82 * * \\
(0.21)\end{array}$ & $\begin{array}{l}-0.79 * * \\
(0.21)\end{array}$ \\
\hline Spin-off & & $\begin{array}{l}-1.27 * * \\
(0.21)\end{array}$ & & & & & $\begin{array}{l}-0.63 * * \\
(0.08)\end{array}$ & $\begin{array}{l}-2.32 * * \\
(0.20)\end{array}$ \\
\hline Post-shift period & & & & $\begin{array}{l}1.00 * \\
(0.46)\end{array}$ & & $\begin{array}{l}-0.35^{+} \\
(0.18)\end{array}$ & $\begin{array}{l}-0.33 * \\
(0.17)\end{array}$ & $\begin{array}{l}-1.01 * * \\
(0.17)\end{array}$ \\
\hline $\begin{array}{l}\text { Spin-off } * \text { Post-shift } \\
\text { period }\end{array}$ & & & & & & & & $\begin{array}{l}2.48 * * \\
(0.21)\end{array}$ \\
\hline Log likelihood & -132.69 & -110.46 & 250.21 & 252.56 & -556.89 & -554.99 & -733.03 & -640.67 \\
\hline Number of banks & 2924 & 2924 & 786 & 786 & 2280 & 2280 & 3068 & 3068 \\
\hline Number of failures & 324 & 324 & 258 & 258 & 1112 & 1112 & 1370 & 1370 \\
\hline
\end{tabular}

\footnotetext{
${ }^{\mathrm{a}}$ Standard errors are shown in parentheses; ${ }^{+} \mathrm{p}<0.1, * \mathrm{p}<0.05, * * \mathrm{p}<0.01$; all models include intercept terms but their coefficients are not reported
} 
Table 4

\section{Maximum Likelihood Estimates of Organizational Mortality after the Regulatory Regime Shift for Banks with Data on Loan Portfolios and Foreign Correspondent Accounts ${ }^{\text {a }}$}

\begin{tabular}{|c|c|c|c|c|c|}
\hline Variables & Model 1 & Model 2 & Model 3 & Model 4 & Model 5 \\
\hline Competition intensity & $\begin{array}{c}0.65 \\
(0.42)\end{array}$ & $\begin{array}{c}0.78 \\
(0.47)\end{array}$ & $\begin{array}{c}0.78 \\
(0.47)\end{array}$ & $\begin{array}{c}0.77 \\
(0.47)\end{array}$ & $\begin{array}{c}0.77 \\
(0.47)\end{array}$ \\
\hline Competition intensity sq. & $\begin{array}{l}-0.02 * \\
(0.01)\end{array}$ & $\begin{array}{l}-0.02 * \\
(0.01)\end{array}$ & $\begin{array}{l}-0.02 * \\
(0.01)\end{array}$ & $\begin{array}{l}-0.02 * \\
(0.01)\end{array}$ & $\begin{array}{l}-0.02 * \\
(0.01)\end{array}$ \\
\hline Competition at founding & $\begin{array}{l}-0.07 \\
(0.09)\end{array}$ & $\begin{array}{l}-0.09 \\
(0.11)\end{array}$ & $\begin{array}{l}-0.11 \\
(0.11)\end{array}$ & $\begin{array}{l}-0.05 \\
(0.11)\end{array}$ & $\begin{array}{l}-0.07 \\
(0.11)\end{array}$ \\
\hline $\begin{array}{l}\text { Organizational size } \\
\text { (1994) }\end{array}$ & $\begin{array}{l}0.00 * * \\
(0.00)\end{array}$ & $\begin{array}{c}0.00^{* *} \\
(0.00)\end{array}$ & $\begin{array}{c}0.00 * * \\
(0.00)\end{array}$ & $\begin{array}{c}0.00^{* *} \\
(0.00)\end{array}$ & $\begin{array}{l}0.00^{* *} \\
(0.00)\end{array}$ \\
\hline Organizational age & $\begin{array}{l}-0.29 \\
(0.44)\end{array}$ & $\begin{array}{l}-0.36 \\
(0.51)\end{array}$ & $\begin{array}{l}-0.42 \\
(0.52)\end{array}$ & $\begin{array}{l}-0.18 \\
(0.53)\end{array}$ & $\begin{array}{l}-0.27 \\
(0.53)\end{array}$ \\
\hline Moscow & $\begin{array}{r}0.05 \\
(0.17)\end{array}$ & $\begin{array}{l}-0.07 \\
(0.21)\end{array}$ & $\begin{array}{l}-0.15 \\
(0.21)\end{array}$ & $\begin{array}{l}-0.15 \\
(0.21)\end{array}$ & $\begin{array}{l}-0.23 \\
(0.21)\end{array}$ \\
\hline St Petersburg & $\begin{array}{l}-0.58 \\
(0.48)\end{array}$ & $\begin{array}{l}-0.48 \\
(0.61)\end{array}$ & $\begin{array}{l}-0.59 \\
(0.61)\end{array}$ & $\begin{array}{l}-0.45 \\
(0.61)\end{array}$ & $\begin{array}{l}-0.57 \\
(0.61)\end{array}$ \\
\hline Foreign ownership & $\begin{array}{c}-1.37^{* *} \\
(0.30)\end{array}$ & $\begin{array}{c}-1.48^{* *} \\
(0.36)\end{array}$ & $\begin{array}{c}-1.50^{* *} \\
(0.36)\end{array}$ & $\begin{array}{c}-1.39 * * \\
(0.35)\end{array}$ & $\begin{array}{l}-1.42^{* *} \\
(0.35)\end{array}$ \\
\hline Industry age & $\begin{array}{l}-0.21 \\
(0.49)\end{array}$ & $\begin{array}{l}-0.09 \\
(0.56)\end{array}$ & $\begin{array}{l}-0.03 \\
(0.57)\end{array}$ & $\begin{array}{l}-0.28 \\
(0.58)\end{array}$ & $\begin{array}{l}-0.19 \\
(0.58)\end{array}$ \\
\hline Spin-off & $\begin{array}{l}-0.32 \\
(0.18)\end{array}$ & $\begin{array}{l}-0.35 \\
(0.21)\end{array}$ & $\begin{array}{c}0.46 \\
(0.43)\end{array}$ & $\begin{array}{l}-0.16 \\
(0.23)\end{array}$ & $\begin{array}{c}0.71 \\
(0.45)\end{array}$ \\
\hline $\begin{array}{l}\text { Loans to private } \\
\text { enterprises }\end{array}$ & & $\begin{array}{c}0.00 \\
(0.01)\end{array}$ & $\begin{array}{c}0.01 \\
(0.01)\end{array}$ & $\begin{array}{l}0.00 \\
(0.01)\end{array}$ & $\begin{array}{c}0.01 \\
(0.01)\end{array}$ \\
\hline Loans to SOEs & & $\begin{array}{l}-0.01 \\
(0.01)\end{array}$ & $\begin{array}{l}-0.01 \\
(0.01)\end{array}$ & $\begin{array}{l}-0.01 \\
(0.01)\end{array}$ & $\begin{array}{l}-0.01 \\
(0.01)\end{array}$ \\
\hline Loans to individuals & & $\begin{array}{c}0.01 \\
(0.01)\end{array}$ & $\begin{array}{c}0.01 \\
(0.01)\end{array}$ & $\begin{array}{l}0.01 \\
(0.01)\end{array}$ & $\begin{array}{c}0.01 \\
(0.01)\end{array}$ \\
\hline $\begin{array}{l}\text { Spin-off*Loans to } \\
\text { private enterprises }\end{array}$ & & & $\begin{array}{l}-0.02 * \\
(0.01)\end{array}$ & & $\begin{array}{l}-0.02 * \\
(0.01)\end{array}$ \\
\hline $\begin{array}{l}\text { Foreign } \\
\text { correspondents }\end{array}$ & & & & $\begin{array}{c}0.01 \\
(0.01)\end{array}$ & $\begin{array}{c}0.01 \\
(0.01)\end{array}$ \\
\hline $\begin{array}{l}\text { Spin-off*Foreign } \\
\text { correspondents }\end{array}$ & & & & $\begin{array}{l}-0.04 * \\
(0.02)\end{array}$ & $\begin{array}{l}-0.04 * \\
(0.02)\end{array}$ \\
\hline Constant & $\begin{array}{c}419.54 \\
(984.94)\end{array}$ & $\begin{array}{c}183.25 \\
(1124.47)\end{array}$ & $\begin{array}{c}50.37 \\
(1130.86)\end{array}$ & $\begin{array}{c}554.51 \\
(1145.36)\end{array}$ & $\begin{array}{c}368.92 \\
(1147.81)\end{array}$ \\
\hline Log likelihood & -450.49 & -351.85 & -349.56 & -346.59 & -344.07 \\
\hline Number of banks & 414 & 332 & 332 & 326 & 326 \\
\hline Number of failures & 195 & 154 & 154 & 154 & 154 \\
\hline
\end{tabular}

${ }^{a}$ Loan portfolios and foreign correspondent accounts as of the end of 1994. Standard errors are shown in parentheses.

$* \mathrm{p}<0.05$

$* * \mathrm{p}<0.01$ 
Figure 1a

Hypotheses that compare restructuring spin-offs with de novo organizations

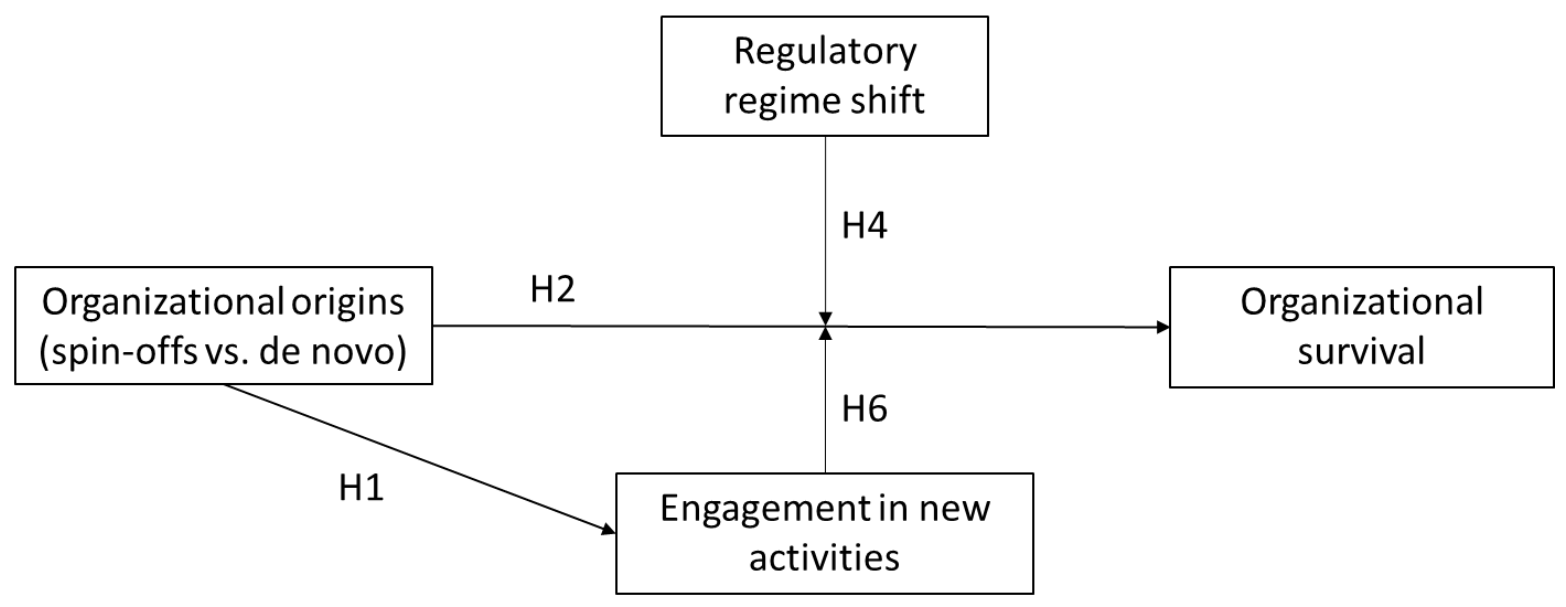

Figure 1b

Hypotheses about conditions affecting survival of restructuring spin-offs

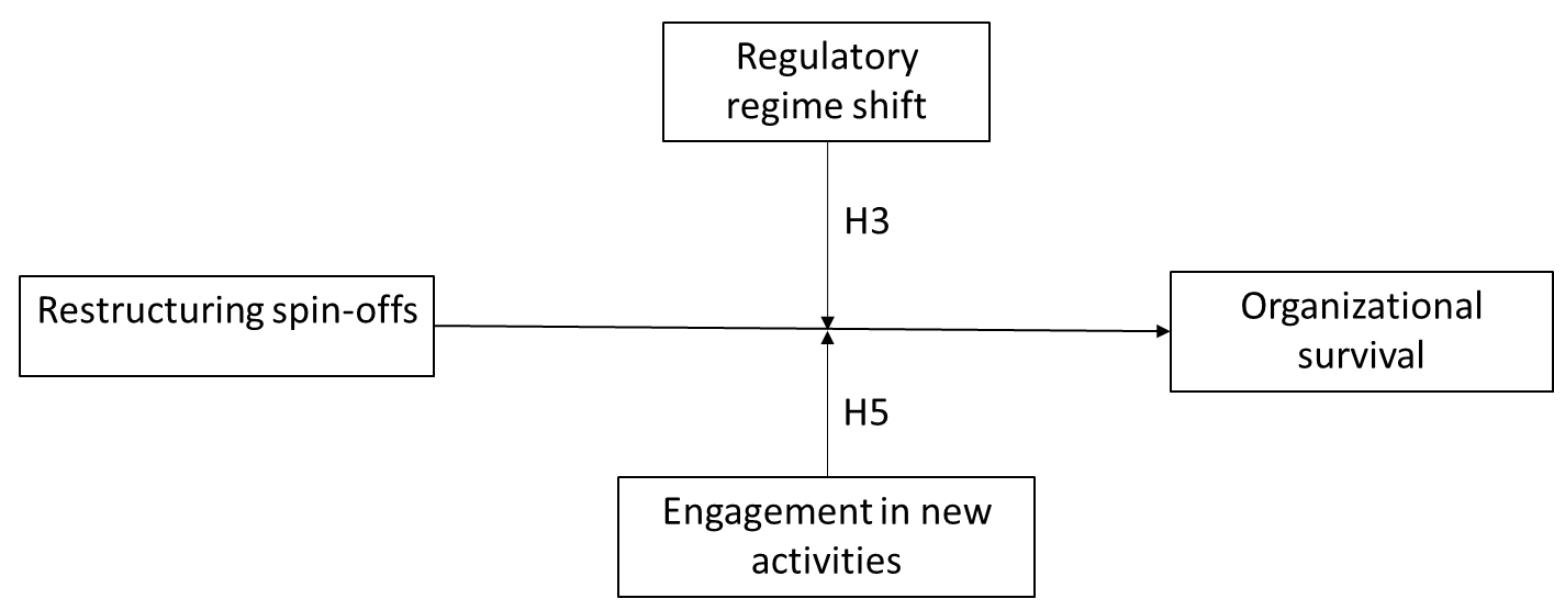




\section{APPENDIX}

\section{Information about prior employment of top managers of a spin-off bank and a de novo bank}

\begin{tabular}{|c|c|}
\hline $\begin{array}{l}\text { Spin-off bank: Top management team of Bezhitsa-bank in } 1994 \\
\text { (spun off from PSB state bank in 1990) }\end{array}$ & $\begin{array}{l}\text { De novo bank: Top management team of Bizon-kapital in } 1994 \\
\text { (founded in 1992) }\end{array}$ \\
\hline $\begin{array}{l}\text { Head of Governing Body: Grishkova L.E. } \\
\text { (previous workplace: Bezhitskij branch of PSB state bank) } \\
\text { Deputy Head of Governing Body: Vorontsova L.D. } \\
\text { (previous workplace: Bezhitskij branch of PSB state bank) } \\
\text { Deputy Head of Governing Body: Izotova G.V. } \\
\text { (previous workplace: Bezhitskij branch of PSB state bank) } \\
\text { Member of Governing Body: Krotov A.R. } \\
\text { (previous workplace: Bryansk Electromechanical Plant) } \\
\text { Member of Governing Body: Kuznetsova T.A. } \\
\text { (previous workplace: Bezhitskij branch of PSB state bank) } \\
\text { Member of Governing Body: Prudnikova T.I. } \\
\text { (previous workplace: Bezhitskij branch of PSB state bank) } \\
\text { Member of Governing Body: Sidorenkova A.V. } \\
\text { (previous workplace: Bezhitskij branch of PSB state bank) }\end{array}$ & $\begin{array}{l}\text { Head of Governing Body: Bazhenov A.V. } \\
\text { (previous workplace: Marijskij Polytechnic Institute and “Ayar" } \\
\text { commercial bank) } \\
\text { First Deputy Head of Governing Body: Trunin V.G. } \\
\text { (previous workplace: Khabarovsk Polytechnic Institute and } \\
\text { cooperative "Kurs") } \\
\text { Deputy Head of Governing Body: Bajbarodina V.G. } \\
\text { (previous workplace: Khabarovsk Institute of National Economy) } \\
\text { Deputy Head of Governing Body: Gur'ev V.V. } \\
\text { (previous workplace: Dalnevostochnij Science and Research Institute) } \\
\text { Member of Governing Body: Balakhonova M.I. } \\
\text { (previous workplace: "Regionalnoe Razvitie" commercial bank and } \\
\text { Khabarovsk Department of the Central Bank of Russia) } \\
\text { Member of Governing Body: Peskova T.D. } \\
\text { (previous workplace: Small Enterprises Development Center of } \\
\text { Khabarovsk Municipal Government) } \\
\text { Member of Governing Body: Pytnev V.V. } \\
\text { (previous workplace: Khabarovsk Polytechnic Institute) }\end{array}$ \\
\hline
\end{tabular}

Source: Intelbridge directory of Russian banks, 1994. 